\title{
Causes of Increasing Demand of Employees Outsourcing and Its Impact on Pakistan Business
}

\author{
Muneeb Ahmad \\ MS-Management Sciences (Finance), Riphah International University Islamabad \\ Pakistan \\ E-mail. Muneeb112@gmail.com \\ Kashif Raza \\ Student of MS (Finance), Riphah School of leadership \\ Riphah International University Islamabad Pakistan \\ E-mail: kashifrazafsd@yahoo.com

\begin{abstract}
Rana Naeem Shahid
MS-Management Sciences, Assistance Professor Informatics College Faisalabad Pakistan

E-mail: naeemtuf@yahoo.com
\end{abstract}

Accepted: May 28, 2012 Published: June 18, 2012

Doi:10.5296/ijld.v2i3.1966 URL: http://dx.doi.org/10.5296/ijld.v2i3.1966

\begin{abstract}
:
This research paper is fundamentally builds the notion about the outsourcing and benefits as a part of the Human Resource Management system. These days outsourcing well thought-out as the variable of industrialized merchandise to countries provided that contemptible labor throughout the Industrial insurgence. Outsourcing of conventionally municipal segment services has become a widespread carry out in many countries around the globe. Most of the study in this area concentrates on improving efficiency and achieving financial savings. Here we are going to discuss the recompenses and disadvantages of outsourcing for Pakistani industry. For collection of data Questionnaire and interviews are conducted into different service industries all the way through statistical tools and the SPSS will be used to analyze these data quantify.
\end{abstract}

Keyword: IT outsourcing, Services industry, employment problems, Pakistan

\section{Introduction:}

The foreign countries are providing cheap labour to another country for the purpose of getting more profit. In a world where information technology has become the backbone of the 
businesses while Outsourcing is a process through which one organization can hand over its work to another company and the organization is responsible for the certain business processes under the requirement of the organization or country.

What is outsourcing? A foremost HR journal defined it as "having an outdoor vendor supply, on a frequent basis, an overhaul that would usually be performed within the institute."Simply situate, outsourcing is the assessment made by a business to pay one more firm to do something that, in theory, it could do itself (Byham, 1996).

The idea of outsourcing has its roots in the spirited benefit theory propagated by Adam Smith in his book 'The Wealth of Nations'. more than the time, the connotation of the word 'outsourcing' has passed through a transformation of opinion What happening off as the variable of industrialized goods to countries providing cheap labor during the Industrial rebellion, has taken on a new association in today's circumstances. (By Nandita Sethi, 2008).

Outsourcing is not a narrative conception. Business processes such a task force administration; printing and promotion have been slight to peripheral suppliers for decades. However, IT outsourcing is a comparatively fresh practice, in spite of some in contention it is similar to the computer department services of the 1960s and 1970s. Key distinctions between then and now consist of: (Aalders).

Outsourcing in today world is a strategic too "the transfer of services, where if applicable, the accompanying employees and resources are transferred to a specialized service provider and consequently (Delen, 2009)" that is used for cost diminution and it helps the organization to attain the company objectives through operational efficiency to make better market position. The main rationale of this research is to recognize that what are the reasons to outsource the man power (labor) form one nation to another nation or one association to another and what problems create through the outsourcing like unemployment, low level of motivation and so many problems. The outsourcing is normally used by Government agencies, Banks, Health, Manufactures and insurance companies.

Another triumphant of outsourcing is set up in human resources. An investigation of human executives exposed 85 percent have personal experience leading an outsourcing effort within their organization. In addition, it was found that two-third of pension departments have outsourced at least one human resource function. For fascinating examples from Pakistan, still Pakistan vestiges distant following India. Last year the country's software and IT services business hit just $\$ 300$ million and exports made up only about $11 \%$ of that. (Pearce, 2008)

Many Pakistani citizens who have returned from USA and England have played a foremost rule in enriching many industries in Pakistan. Greater part of these people can talk better English these days. They discern very well American and British political affairs, cultures, composition, and so on. Especially, agents in Karachi, Lahore, and Islamabad are very well qualified. Young Pakistanis are working very well to boost up not just in media or music but they are playing their function to uplift the new call center business (Abedin, 2006).

"Outsourcing saves time, outsourcing saves money, outsourcing expands your awareness base and outsourcing builds your owner trademark. (Shantell Malachi, 2011)"

Small businesses that are irritating to enlarge new software products can also advance their services with outsourcing. Usually, smaller companies have slighter assets to build up software 
solutions for themselves. They are left with two options, either to appoint new expertise or consign this job to a peripheral business (Primus, 2009).

Consulting management firm AT Kearney Reports, "Pakistan has developed into the 20th most gorgeous outsourcing goal. Even as concern raise about Pakistan's loyalty and the rising displaced populace due to habitual military operation with the Terrorists, the country made a considerable jump on AT Kearney's 2009 Global Services position directory released May 18. Pakistan has gone from number 30 in 2007 to number 20 in 2009" (Kearney's, 2009).

IT outsourcing involves the constricting out of information technology services, like the fitting of hard- and software, computer system preservation, user support and prop up, etc., to an external service contributor. (Ohnemus, 2010)

Smaller number holidays in Pakistan ways less instance of slipping in staff ease of use compared to India. IT firms in India are advised to hire miscellaneous personnel so that members of one society can enjoy important festivals while members of other communities cover the phones and keep manufacturing going. (Specialist, 2008)

This outsourcing process is useful to both the outsourcing company and the outsourcing service provider. In an outsourcing relationship, the outsourcing service provider enables the outsourcer to reduce operating costs, increase quality in non-core areas of business, save on attempt and increase in production.

Companies that outsource jobs to overseas countries heighten joblessness and are the main cause why we have had the same lowest wage rate for 9 years. Smallest amount wage was $\$ 5.15$ for each hour since 1997(Gilman, 05 November 2009).

The company outsources more outfitted task to contend in the worldwide marketplace. For this study, a research is conduct by interviewing through a survey using questionnaire. With the help of the research this study gets approaching into the most recent features that are used in the compensation and benefits.

\section{LITERATURE REVIEW}

What is outsourcing? A foremost HR journal defined it as "having an outdoor vendor supply, on a frequent basis, an overhaul that would usually be performed within the institute."Simply situate, outsourcing is the assessment made by a business to pay one more firm to do something that, in theory, it could do itself. Once characterizing relations with managerial service providers such as mailroom operations and data dispensation (Byham, 1996).

Outsourcing of some actions to a far-away site has developed into possible due to the development of information technology (IT). Such cross-border IT based services, usually termed IT enabled services, are functions that are provided from one site to another over telecommunication or data networks (through wire line or wireless devices) and are either outwardly fine (third party outsourcing) or provided by are mote auxiliary of the same company (confined BPO).

Many of the eminent worldwide overseas companies such as GE Capital's, Hewlett Packard, and Bechtel are benefited by locating their subsidiaries in price tag valuable countries like Pakistan (Akram, march 2011). 
Outsourcing is capable to reduce costs in industries, add to aptitude, flexibility and litheness and consequence in other progress. Offshore outsourcing entail free buy and sell free capital mobility. Additionally, offshore outsourcing, as well as trade and opposition in universal are useful for the source and the state of a fresh source. (Sylvia Ritt, 2006).

Outsourcing is one technique that companies have to help them manage with outer services. Once functions are outsourced, the company no longer requirements to be anxious about staying up on the "newest and utmost" technology or judgment the "best business performance" the outsource supplier does this. Many organizations tend to come up to outsourcing strategically, looking for temporary reserves at the expenditure of enduring gains. (Rana, Syed, \& Muhammad, 31. December 2011).

People of Pakistan realize the notion of HR outsourcing but the perception of Human Capital administration is exceptional folded. Organizations are outsourcing Human resource but they just manage this to operations the procedures and all activities, which are indispensable to be ended by them. Most of the Organizations are ignorant from the factual essence of this idea that it is highly cost productive and assists to gain competitive advantage. Apart from these, the outsourcing firms assist not only to provide the human resource, they aid in developing, training and compensating the workers. (Rana Tariq Mehmood1, Fall 2011).

By distinction, the domestic manufacturing by some firms of lower-tech medical apparatus, such as simple surgical instruments, is habitually supplemented by importing like completed products from low-wage countries and reselling them on the family market after transport out trouble-free tasks such as excellence control measures and wrapping. Some of the price differentials in this segment are enormously big; for example, simple scalpels sold by single UK firm for 25 pounds can be purchased from Pakistani companies for one pound! Therefore the price incentives to subcontract can be considerable (OSCARSSON, 2002).

The major attention was one of the main tactical issues the sourcing matter, which was how to decide on and appraise suppliers in the sourcing progression. The first purpose of this research were sequence operations to scrutinize present existing contractor. Supplier Performance and determine their potentials in textile the second objective was to determine (Osman, 2010).

Outsourcing, expenditure pressures and cost-effective volatility have pressed companies into reevaluating their business strategies. Outsourcing has become additional of a requirement than sumptuousness to convene these challenges. Companies require modifying products but also custody costs small at the equivalent time, resorting to accumulation manufacturing techniques. Progression Pakistan Outsourcing Group helps in calculating these processes. civilizing superiority, production competence and plummeting in general costs are the other goals (Group E. p., 2011).

Political unsteadiness, communications dilemma, high abrasion rate, antagonism in Outsourcing market, intimidation, contradictory Policies of one government are favoring for a certain industry at the same time as the very next government changes its priorities benefit losing then it becomes a big predicament for a main river financier. (Admin, 2009).

Permanent workers can't be outsources except they are negotiated by offering gorgeous remuneration for switching from undeviating to outsource employee and taken sanction in writing from employee in sort to keep away from officially permitted haziness. Contractual employees can be outsourced after achievement of agreement era or finish as per obligation. 
Provisional employees can be outsourced behind achievement of phase or come to an end if not necessary. Consultants formerly not on company payroll but a fee are compensated depending upon the assignment (Attaa, 2009).

Outsourcing brings a swarm of benefit save large! Acquire pro of the cost reimbursement get right to use to particular services diminish time to liberation well on point in time scale operations up or down lacking the harass of hiring and preparation enhanced customer contentment due to high superiority \& quick delivery see a supplement in your business create more rapidly deliveries to your patrons and see your business development (Group E. P., 2012).

Exploring work-related characteristics allows us to recognize two supplementary and exclusive associations. First, occupations that depiction personnel to potentially dangerous operational state practice remuneration drops after outsourcing. Second, not all degrees are shaped equivalent. Occupations that intensively utilize knowledge sets from societal discipline and languages are scientifically less exaggerated by outsourcing shocks, at the same time as individuals that employ facts sets from natural sciences and manufacturing are no additional or less insulated from outsourcing shocks than the regular industrialized employee. (Hummels, 2010)

According to Lehman, Pakistan's advantages include relatively low wages - amounting to as little as half the level of salaries in India - as well as reasonable real estate costs, plentiful government incentives and a readily available supply of workers. (Kowalski, 2007)

By contrast, the domestic production by some firms of lower-tech medical equipment, such as simple surgical instruments, is frequently supplemented by importing similar finished products from low-wage countries and reselling them on the domestic market after carrying out simple tasks such as quality control procedures and packaging. Some of the price differentials in this sector are extremely large; for example, simple scalpels sold by one UK firm for 25 pounds can be purchased from Pakistani companies for one pound! Hence the price incentives to outsource can be substantial (OSCARSSON, 2002).

Trade also has a unenthusiastic impact on the demand for not as much of well-informed workers, but it is not linked with an enhance in requirement for further educated employees. Outsourcing appears include relatively small negative collision on demand transversely all education levels; with the strongest belongings for employees with less than a institution degree. Maybe our the largest part attractive consequence concerns the relations among trade and computers (Siegel, 2000)

A right through assessment of the literature leads to the conclusion that the horror of job-losses due to outsourcing is repeatedly superior to the definite menace. The literature indicates that worldwide outsourcing might even comprise an affirmative net effect on the quality and measure of employment in the industrialized countries. Consequently, the naive concept of jobs being "exported" on or after one state to a new is over and over again disingenuous (Peter Auer, 2006).

For the Pakistan outsourcing industry, technologies in the form of cloud computing, web services, virtualization and new media, social networking, etc., and the demand for increasingly complex software and software-enabled services will most likely enable it to ride another outsourcing boom in another 2-3 years. In October, 2008, when the downturn was 
dying out, research companies dedicated to outsourcing carried out surveys of major clients. As per their research, Pakistan's software and BPO industry is projected to grow by 10 per cent annually till 2010-11 to log export revenues alone of \$20-32billion (BY ADMIN, 2011)

For small to mid-sized organizations, the compensation of outsourcing array completion to boost up customer contentment throughout swiftness, precision, and customer service are comprehensible (Warner, 2011)

The presence of technological skills was absolutely connected to the outsourcing assessment.it chains the thought from imperfect convention assumption stating that tricks ought to be underneath the control of the revelry assembling the serious speculation for the business deal. On the other hand, business skills did not give the impression to participate a considerable function in the judgment to outsource (By Hans Solli-Saether, 2011)

At the same time as external suppliers and mannufacturers can every so often offer products and services at a inferior cost than doing it physically, the most important fiscal motive for choosing an outsourcing elucidation is to formulate costs more unsurprising and set up a smoother cash flow (Barrow, 2009).

Get better Business focal point, grow right to use to superlative Capabilities, go faster Reengineering reimbursement, Share Risks, transmit IS possessions to further deliberated actions, One time applications, diminish or Control Operating expenses, Make principal cremation obtainable, safe and sound assets not presented inside (Quoquam Technologies, 2012).

Lower the entire outlay of possession by astringent Avanade to handle your Microsoft applications and communications below a overhaul level-based conformity. Avanade Outsourcing also includes a series of cloud-based services in which you compensate just for the services you employ. You'll obtain the matching applications you're previously using, except at a fraction of the cost (Avanade, 2010).

In the past, outsourcing was just an entrusting profession of non-core commerce. On the other hand currently, it is utilized as a piece of business tactic in sort to bestow concentration to on center business . Outsourcers increase their business to whole outtsourcing services or aim to upgrade their specialty. Future development of outsourcing would proceed to full outsourcing of strategic utilization and high level professional services (keyasu, 2004).

On the subject of employment own assets, a number of studies have provided estimates of the potentially vanished jobs unpaid to offshoring but fewer consideration has been rewarded to outsourcing in a auxiliary widespread sense. From a worldwide peak of observation outsourcing and fractional repositioning together generate and demolish jobs, in the intellect that at several one is in receipt of a job and someone is conceding a profession (Suriñach, 2007).

In recent times outsourcing has turn out to be big information as managerial jobs in areas such as telecommunications and information machinery have been outsourced to overseas human resources. American recruits with high-paying trouble-free jobs have had the memorable hearth rug pulled out from underneath them and are howling soiled, outlying and extensive. It is fairly ordinary that they would not be paying concentration in the gainful actuality that such outsourcing is imperative to the cost-cutting measure and their own long-run profitable 
interest. Outsourcing, both foreign and familial, is critical not just for cutback recent jobs, but too for original job establishment (Thornton, 2004).

Outsourcing is flattering a significant deliberation in today's MIS world. The foremost outsourcing measures are the fractional reassign of computing tricks and the entire rummage sale of all computer property (Wagner, 1992)

\section{Hypothesis:}

$\mathrm{H}_{1}$ :

To make organization competitive through advanced skilled employees is the significant Cause of employees outsourcing.

$\mathrm{H}_{\mathrm{O}}$ :

To make organization competitive through advanced skilled employees is not the significant cause of employees outsourcing.

$\mathrm{H}_{2:}$

The outsourcing is done due to the reduction of costs of services.

$\mathrm{H}_{\mathrm{o}}$ :

The outsourcing is not done due to the reduction of the costs of services

\section{RESEARCH METHODLOGY}

\section{Quantitative Method}

In the research methodology quantitative method have been selected because the data collected from the questionnaire can be measured through statistical tools and the SPSS will be used to calculate these data measure.

\section{Research Design}

Questionnaire and interview have been used for the purpose of collection of primary data.

\section{Population and sample:}

\section{Population}

Services industry has been taken for the purpose of research.

\subsubsection{Sample and sampling Method}

I have selected 23 people from the different sector as it is mentioned in the below table.

Table: 1

\begin{tabular}{|l|l|}
\hline Categories & $\begin{array}{l}\text { Sample } \\
\text { size }\end{array}$ \\
\hline Industrial Sector & 8 \\
\hline Bank Sector & 7 \\
\hline
\end{tabular}




\begin{tabular}{|l|l|}
\hline Educational Sector & 8 \\
\hline Total & $\mathbf{2 3}$ \\
\hline
\end{tabular}

\subsection{Research Instrument}

During the research I have developed the research instrument questionnaire in the form of

$>$ Open- ended questions.

$>$ Close- ended questions.

Developed 25 questions which contains firstly introduction of participant and the remaining questions present the problem in the form of open ended and close ended questions.

\subsection{Procedure for data collection}

Prepare the questionnaire for the purpose of data collection from different organizations.

\section{Data Analysis and Interpretation:}

For the analysis of data SPSS is used and different tables are used for interpretation of data.

\begin{tabular}{|c|c|c|c|c|c|}
\hline & & $\begin{array}{l}\text { Frequenc } \\
\mathrm{y}\end{array}$ & Percent & $\begin{array}{l}\text { Valid } \\
\text { Percent }\end{array}$ & $\begin{array}{l}\text { Cumulative } \\
\text { Percent }\end{array}$ \\
\hline \multirow[t]{16}{*}{ Valid } & 21 & 2 & 8.7 & 8.7 & 8.7 \\
\hline & 22 & 5 & 21.7 & 21.7 & 30.4 \\
\hline & 23 & 3 & 13.0 & 13.0 & 43.5 \\
\hline & 24 & 1 & 4.3 & 4.3 & 47.8 \\
\hline & 26 & 2 & 8.7 & 8.7 & 56.5 \\
\hline & 27 & 1 & 4.3 & 4.3 & 60.9 \\
\hline & 30 & 1 & 4.3 & 4.3 & 65.2 \\
\hline & 31 & 1 & 4.3 & 4.3 & 69.6 \\
\hline & 33 & 1 & 4.3 & 4.3 & 73.9 \\
\hline & 45 & 1 & 4.3 & 4.3 & 78.3 \\
\hline & 52 & 1 & 4.3 & 4.3 & 82.6 \\
\hline & 55 & 1 & 4.3 & 4.3 & 87.0 \\
\hline & 56 & 1 & 4.3 & 4.3 & 91.3 \\
\hline & 58 & 1 & 4.3 & 4.3 & 95.7 \\
\hline & 59 & 1 & 4.3 & 4.3 & 100.0 \\
\hline & Total & 23 & 100.0 & 100.0 & \\
\hline
\end{tabular}

\section{Explanation}

The partcipents are different ages that are 21,22,23,27, and 59 years persons that fillout the questionnaires. 
Are skills necessary?

\begin{tabular}{|c|c|c|c|c|c|}
\hline & & Frequency & Percent & $\begin{array}{l}\text { Valid } \\
\text { Percent }\end{array}$ & $\begin{array}{l}\text { Cumulative } \\
\text { Percent }\end{array}$ \\
\hline \multirow[t]{6}{*}{ Valid } & Agree & 12 & 52.2 & 52.2 & 52.2 \\
\hline & D.Agree & 1 & 4.3 & 4.3 & 56.5 \\
\hline & Disagree & 5 & 21.7 & 21.7 & 78.3 \\
\hline & S.Agree & 3 & 13.0 & 13.0 & 91.3 \\
\hline & S.Disagree & 2 & 8.7 & 8.7 & 100.0 \\
\hline & Total & 23 & 100.0 & 100.0 & \\
\hline
\end{tabular}

\section{EXPLANATION}

In the above table and in pie chart there are $52 \%$ people in the favor to do outsourcing work where skills are necessary. It means that skills are necessary to perform the in best way and $23 \%$ people who are not agree with this statement.

Are any risks while outsourcing?

\begin{tabular}{|c|c|c|c|c|c|}
\hline & & Frequency & Percent & $\begin{array}{l}\text { Valid } \\
\text { Percent }\end{array}$ & $\begin{array}{l}\text { Cumulative } \\
\text { Percent }\end{array}$ \\
\hline \multirow[t]{5}{*}{ Valid } & Agree & 10 & 43.5 & 43.5 & 43.5 \\
\hline & Disagree & 6 & 26.1 & 26.1 & 69.6 \\
\hline & S.Agree & 5 & 21.7 & 21.7 & 91.3 \\
\hline & S.Disagree & 2 & 8.7 & 8.7 & 100.0 \\
\hline & Total & 23 & 100.0 & 100.0 & \\
\hline
\end{tabular}

\section{EXPLANATION:-}

In the above question the mostly no of respondents are agree that there are more risks while outsourcing. The percentage of agree are $43.5 \%$ shows that high risks faces and on the other side the $35 \%$ people are not agree. 
Does outsource free up cash flows?

\begin{tabular}{|c|c|c|c|c|c|}
\hline & & Frequency & Percent & $\begin{array}{l}\text { Valid } \\
\text { Percent } \\
\end{array}$ & $\begin{array}{l}\text { Cumulative } \\
\text { Percent }\end{array}$ \\
\hline Valid & Agree & 15 & 65.2 & 65.2 & 65.2 \\
\hline & Disagree & 5 & 21.7 & 21.7 & 87.0 \\
\hline & S.Agree & 1 & 4.3 & 4.3 & 91.3 \\
\hline & S.Disagree & 2 & 8.7 & 8.7 & 100.0 \\
\hline & Total & 23 & 100.0 & 100.0 & \\
\hline
\end{tabular}

\section{EXPLANATION:-}

In the above frequency table there are $68 \%$ participant who are agree that the outsourcing free up cash flows and remaining 32\% people are disagree with this question.

Does outsourcing increases unemployment?

\begin{tabular}{|ll|l|l|l|l|}
\hline & & Frequency & Percent & $\begin{array}{l}\text { Valid } \\
\text { Percent }\end{array}$ & $\begin{array}{l}\text { Cumulative } \\
\text { Percent }\end{array}$ \\
\hline Valid & Agree & 14 & 60.9 & 60.9 & 60.9 \\
& Disagree & 6 & 26.1 & 26.1 & 87.0 \\
& S.Agree & 3 & 13.0 & 13.0 & 100.0 \\
Total & 23 & 100.0 & 100.0 & \\
\hline
\end{tabular}

\section{EXPLANATION:-}

In this table the $61 \%$ people are agree the with outsourcing create unemployment in the country and $13 \%$ are strongly agree and $23 \%$ participants are not agree with the above question. 
Are outsourcing improving customer satisfaction?

\begin{tabular}{|c|c|c|c|c|c|}
\hline & & Frequency & Percent & $\begin{array}{l}\text { Valid } \\
\text { Percent }\end{array}$ & $\begin{array}{l}\text { Cumulative } \\
\text { Percent }\end{array}$ \\
\hline \multirow[t]{3}{*}{ Valid } & Agree & 16 & 69.6 & 69.6 & 69.6 \\
\hline & Disagree & 7 & 30.4 & 30.4 & 100.0 \\
\hline & Total & 23 & 100.0 & 100.0 & \\
\hline
\end{tabular}

\section{EXPLANATION:-}

In this question the $70 \%$ participant who are agreeing that the outsourcing create customer satisfaction and $30 \%$ participant who are disagree.

Is outsourcing effective in today saniro?

\begin{tabular}{|c|c|c|c|c|c|}
\hline & & Frequency & Percent & $\begin{array}{l}\text { Valid } \\
\text { Percent }\end{array}$ & $\begin{array}{l}\text { Cumulative } \\
\text { Percent }\end{array}$ \\
\hline \multirow[t]{5}{*}{ Valid } & Agree & 12 & 52.2 & 52.2 & 52.2 \\
\hline & Disagree & 9 & 39.1 & 39.1 & 91.3 \\
\hline & S.Agree & 1 & 4.3 & 4.3 & 95.7 \\
\hline & S.Disagree & 1 & 4.3 & 4.3 & 100.0 \\
\hline & Total & 23 & 100.0 & 100.0 & \\
\hline
\end{tabular}

\section{EXPLANATION:-}

In this above sated question $5 \%$ people who are strongly agree and $53 \%$ are agree with outsourcing is effective now a days and about $40 \%$ participants are not agree.

Is education required to work effectively?

\begin{tabular}{|c|c|c|c|c|c|}
\hline & & Frequency & Percent & $\begin{array}{l}\text { Valid } \\
\text { Percent }\end{array}$ & $\begin{array}{l}\text { Cumulative } \\
\text { Percent }\end{array}$ \\
\hline \multirow[t]{5}{*}{ Valid } & Agree & 13 & 56.5 & 56.5 & 56.5 \\
\hline & Disagree & 3 & 13.0 & 13.0 & 69.6 \\
\hline & S.Agree & 5 & 21.7 & 21.7 & 91.3 \\
\hline & S.Disagree & 2 & 8.7 & 8.7 & 100.0 \\
\hline & Total & 23 & 100.0 & 100.0 & \\
\hline
\end{tabular}

\section{EXPLANATION: -}

In the questionnaire the participant's shows that $56 \%$ are agree and $21 \%$ strongly agree. Approximately $22 \%$ are not agreeing with the statement. 
Are outsourcing make more flexible the nature of business?

\begin{tabular}{|c|l|l|l|l|}
\hline & & Valid & $\begin{array}{l}\text { Cumulative } \\
\text { Percent }\end{array}$ \\
\hline Valid no & 5 & 21.7 & 21.7 & 21.7 \\
yes & 18 & 78.3 & 78.3 & 100.0 \\
Total & 23 & 100.0 & 100.0 & \\
\hline
\end{tabular}

\section{EXPLANATION:-}

In this question the $79 \%$ participants show in that outsourcing make the nature the business more flexible as compare to other businesses and $21 \%$ are not favour of the statement.

Is terminated employees show weakness to competitors?

\begin{tabular}{|c|c|c|c|c|c|}
\hline & & Frequency & Percent & $\begin{array}{l}\text { Valid } \\
\text { Percent }\end{array}$ & $\begin{array}{l}\text { Cumulative } \\
\text { Percent }\end{array}$ \\
\hline \multirow[t]{5}{*}{ Valid } & Agree & 11 & 47.8 & 47.8 & 47.8 \\
\hline & Disagree & 9 & 39.1 & 39.1 & 87.0 \\
\hline & S.Agree & 2 & 8.7 & 8.7 & 95.7 \\
\hline & S.Disagree & 1 & 4.3 & 4.3 & 100.0 \\
\hline & Total & 23 & 100.0 & 100.0 & \\
\hline
\end{tabular}

\section{EXPLANATION:-}

In this question $48 \%$ people who are agree that the terminated employees can show organization weakness to the competitors and $8.7 \%$ people are strongly agree. The $44 \%$ participants are not agreeing.

Do employees fear loss of jobs due to outsourcing?

\begin{tabular}{|c|c|c|c|c|c|}
\hline & & Frequency & Percent & $\begin{array}{l}\text { Valid } \\
\text { Percent }\end{array}$ & $\begin{array}{l}\text { Cumulative } \\
\text { Percent }\end{array}$ \\
\hline \multirow[t]{2}{*}{ Valid } & Agree & 8 & 34.8 & 34.8 & 34.8 \\
\hline & Disagree & 7 & 30.4 & 30.4 & 65.2 \\
\hline
\end{tabular}




\begin{tabular}{|l|l|l|l|l|}
\hline S.Agree & 7 & 30.4 & 30.4 & 95.7 \\
S.Disagree & 1 & 4.3 & 4.3 & 100.0 \\
Total & 23 & 100.0 & 100.0 & \\
\hline
\end{tabular}

\section{EXPLANATION:-}

In this question the participant are strongly agree $31 \%$ and agree $35 \%$. It means that $65 \%$ peoples are agreed and remaining $35 \%$ participants are not agreeing about employees fearing of jobs due to outsourcing.

Does outsourcing access to advanced technology?

\begin{tabular}{|ll|l|l|l|l|}
\hline & & & Valid & $\begin{array}{l}\text { Cumulative } \\
\text { Percent }\end{array}$ \\
\hline Valid & no & 7 & 30.4 & 30.4 & 30.4 \\
& yes & 16 & 69.6 & 69.6 & 100.0 \\
& Total & 23 & 100.0 & 100.0 & \\
\hline
\end{tabular}

\section{EXPLANATION:-}

The $70 \%$ participant's gives comments in the form yes and other $30 \%$ participants give the suggestion they cannot access the advanced technology through outsourcing.

Does outsourcing cause of low motivation?

\begin{tabular}{|ll|l|l|l|l|}
\hline & & & Valid & $\begin{array}{l}\text { Cumulative } \\
\text { Percent }\end{array}$ \\
\hline Valid & Agree & 12 & 52.2 & 52.2 & 52.2 \\
& Disagree & 6 & 26.1 & 26.1 & 78.3 \\
& S.Agree & 4 & 17.4 & 17.4 & 95.7 \\
& S.Disagree & 1 & 4.3 & 4.3 & 100.0 \\
& Total & 23 & 100.0 & 100.0 & \\
\hline
\end{tabular}

\section{EXPLANATION:-}

In the above question there are about $70 \%$ people who are in the favour of they agree with the statement that becomes low level of motivation due to outsourcing

Is any effect of outsourcing on exchange rate?

\begin{tabular}{|l|l|l|l|l|}
\hline & & & $\begin{array}{l}\text { Valid } \\
\text { Percent }\end{array}$ & $\begin{array}{l}\text { Cumulative } \\
\text { Percent }\end{array}$ \\
\hline Valid no & 10 & 43.5 & 43.5 & 43.5 \\
& 13 & 56.5 & 56.5 & 100.0 \\
\hline
\end{tabular}


Is any effect of outsourcing on exchange rate?

\begin{tabular}{|c|c|c|c|c|c|}
\hline & & Frequency & Percent & $\begin{array}{l}\text { Valid } \\
\text { Percent }\end{array}$ & $\begin{array}{l}\text { Cumulative } \\
\text { Percent }\end{array}$ \\
\hline \multirow[t]{3}{*}{ Valid } & no & 10 & 43.5 & 43.5 & 43.5 \\
\hline & yes & 13 & 56.5 & 56.5 & 100.0 \\
\hline & Total & 23 & 100.0 & 100.0 & \\
\hline
\end{tabular}

\section{EXPLANATION:-}

In this question the participants show $57 \%$ in the form of effect of exchange rate and other remaining part of percentage shows in the form of no.

Does outsourcing achieve more with less resource?

\begin{tabular}{|c|c|c|c|c|c|}
\hline & & Frequency & Percent & $\begin{array}{l}\text { Valid } \\
\text { Percent }\end{array}$ & $\begin{array}{l}\text { Cumulative } \\
\text { Percent }\end{array}$ \\
\hline \multirow[t]{4}{*}{ Valid } & Agree & 11 & 47.8 & 47.8 & 47.8 \\
\hline & Disagree & 9 & 39.1 & 39.1 & 87.0 \\
\hline & S.Disagree & 3 & 13.0 & 13.0 & 100.0 \\
\hline & Total & 23 & 100.0 & 100.0 & \\
\hline
\end{tabular}

\section{EXPLANATION:-}

In the question the participants whose are mostly disagree about the outsourcing achieve more with less resources that is $52 \%$ and $48 \%$ are those who are in the favour about this statement

Does outsourcing provide jobs?

\begin{tabular}{|c|c|c|c|c|c|}
\hline & & Frequency & Percent & $\begin{array}{l}\text { Valid } \\
\text { Percent }\end{array}$ & $\begin{array}{l}\text { Cumulative } \\
\text { Percent }\end{array}$ \\
\hline \multirow[t]{5}{*}{ Valid } & Agree & 12 & 52.2 & 52.2 & 52.2 \\
\hline & Disagree & 5 & 21.7 & 21.7 & 73.9 \\
\hline & S.Agree & 4 & 17.4 & 17.4 & 91.3 \\
\hline & S.Disagree & 2 & 8.7 & 8.7 & 100.0 \\
\hline & Total & 23 & 100.0 & 100.0 & \\
\hline
\end{tabular}

\section{EXPLANATION:-}

The

question "does outsourcing provide jobs" show that there are $69 \%$ participants who are in the favor of agree and $31 \%$ are those whose are not agree or disagree about this statement. 


\section{Chi-Square}

Case Processing Summary

\begin{tabular}{|l|l|l|l|l|l|l|}
\hline \multicolumn{2}{|l|}{} & \multicolumn{2}{|l|}{ Cases } & Missing & \multicolumn{2}{l|}{ Total } \\
\cline { 2 - 7 } & Valid & Percent & N & Percent & N & Percent \\
\cline { 2 - 7 } & $\mathrm{N}$ & $100.0 \%$ & 0 & $.0 \%$ & 23 & $100.0 \%$ \\
\hline $\begin{array}{l}\text { does outsourcing cause of } \\
\text { low motivation? } * \text { does } \\
\text { outsourcing provide jobs? }\end{array}$ & 23 & & & & & \\
\hline
\end{tabular}

Does outsourcing cause of low motivation? * does outsourcing provide jobs? Cross tabulation

\begin{tabular}{|c|c|c|c|c|c|c|c|}
\hline & \multicolumn{4}{|c|}{ does outsourcing provide jobs? } & \multirow[b]{2}{*}{ Total } \\
\hline & & & Agree & Disagree & $\begin{array}{l}\text { Strongly } \\
\text { Agree }\end{array}$ & $\begin{array}{l}\text { Strongly } \\
\text { Disagree }\end{array}$ & \\
\hline \multirow{8}{*}{$\begin{array}{l}\text { Does outsourcing } \\
\text { cause of low } \\
\text { motivation? }\end{array}$} & Agree & Count & 5 & 1 & 4 & 2 & 12 \\
\hline & & Expected Count & 6.3 & 2.6 & 2.1 & 1.0 & 12.0 \\
\hline & Disagree & Count & 3 & 3 & 0 & 0 & 6 \\
\hline & & Expected Count & 3.1 & 1.3 & 1.0 & .5 & 6.0 \\
\hline & Strongly & Count & 3 & 1 & 0 & 0 & 4 \\
\hline & Agree & Expected Count & 2.1 & .9 & .7 & .3 & 4.0 \\
\hline & Strongly & Count & 1 & 0 & 0 & 0 & 1 \\
\hline & Disagree & Expected Count & .5 & .2 & .2 & .1 & 1.0 \\
\hline \multirow{2}{*}{\multicolumn{2}{|c|}{ Total }} & Count & 12 & 5 & 4 & 2 & 23 \\
\hline & & Expected Count & 12.0 & 5.0 & 4.0 & 2.0 & 23.0 \\
\hline
\end{tabular}

Chi-Square Tests

\begin{tabular}{|l|l|l|l|}
\hline & Value & df & $\begin{array}{l}\text { Asymp. Sig. } \\
\text { (2-sided) }\end{array}$ \\
\hline Pearson Chi-Square & 10.031 & 9 & .348 \\
Likelihood Ratio & 12.141 & 9 & .205 \\
N of Valid Cases & 23 & & \\
\hline
\end{tabular}

a. 15 cells $(93.8 \%)$ have expected count less than 5 . The minimum expected count is .09 .

Results: value is greater that' accept the hypothesis 


\section{Macrothink}

\section{RECOMMADATIONS AND CONCLUSION}

\section{Findings:-}

Findings are based on my knowledge and questionnaire which were distributed to the different peoples in different service organizations.

In the result of question are skills necessary for outsourcing? I find out that there are $52 \%$ people in the favor to do outsourcing work where skills are necessary. It means that skills are necessary to perform the in best way and $23 \%$ people who are not agree with this statement.

In this question are any risks while outsourcing? The mostly no of respondents are agree that there are more risks while outsourcing. The percentage of agree are $43.5 \%$ shows that high risks faces and on the other side the $35 \%$ people are not agree.

In the question does outsource free up cash flows? the frequency table explaining there are $68 \%$ participant who are agree that the outsourcing free up cash flows and remaining $32 \%$ people are disagree with this question.

In the resulting of question does outsourcing increases unemployment? That $61 \%$ people are agree the with outsourcing create unemployment in the country and $13 \%$ are strongly agree and $23 \%$ participants are not agree with the question. it means that $74 \%$ people are in faour of outsourcing creating unemployment in the country.

Are outsourcing improving customer satisfaction? The resulting of explaining the $70 \%$ participant who are agreeing that the outsourcing create customer satisfaction and $30 \%$ participant who are disagree.

In the explaining the question is outsourcing effective in today sanairo? 13 people who are $5 \%$ strongly agreed and $53 \%$ are agreeing with outsourcing are effective now a days and about $40 \%$ participants are not agree.

In this question Is education required to work effectively? The participant's shows that 56 $\%$ are agree and $21 \%$ strongly agree. Approximately $22 \%$ are not agreeing with the statement.

In this question are outsourcing make more flexible the nature of business? The $79 \%$ participants show in that outsourcing make the nature the business more flexible as compare to other businesses and $21 \%$ are not favor of the statement.

In this question is terminated employees show weakness to competitors? $48 \%$ people who are agree that the terminated employees can show organization weakness to the competitors and $8.7 \%$ people are strongly agreed. The $44 \%$ participants are not agreeing. Do employees fear loss of jobs due to outsourcing? In this question the participant are strongly agree $31 \%$ and agree $35 \%$. It means that $65 \%$ peoples are agreeing and remaining $35 \%$ participants are not agreeing about employees fearing of jobs due to outsourcing.

Does outsourcing access to advanced technology? The $70 \%$ participant's gives comments in the form yes and other $30 \%$ participants give the suggestion they cannot access the advanced technology through outsourcing.

Does outsourcing cause of low motivation? In this question there are about $70 \%$ people who are in the favor of they agree with the statement that becomes low level of motivation due to outsourcing. 
Is there any effect of outsourcing on exchange rate? In this question the participants show $57 \%$ in the form of effect of exchange rate and other remaining part of percentage shows in the form of no.

Does outsourcing achieve more with less resource? In the question the participants whose are mostly disagree about the outsourcing achieve more with less resources that is $52 \%$ and $48 \%$ are those who are in the favor about this statement.

Does outsourcing provide jobs? The question explaining that there are $69 \%$ participants who are in the favor of agree and $31 \%$ are those whose are not agree or disagree about this statement.

\subsection{Conclusions}

For the many years the outsourcing are made for cost saving and reduction. To have a successful of outsourcing you must have to need necessary skills to perform the job, an employer should be skilled like good communication, manage the performance to ensure that the skill needed for organizational success.

The organizations faces a lot of problem while making outsourcing like the services offered by an organization which are not meet the quality of services and many more problems and lose of control on employees. There are no check and balance on the outsourced employees and not quality assurance is given.

Due to outsourcing the employee's fear of job losses because there is less cost bearing and less expenses on the outsourced employees and they have not made payment for retirement plans and other facilities.

The outsourcing gives the benefits of cash flows free whenever the services or products are outsourced. The participants are mostly in the favor of that the cash are free when outsourcing is made.

The outsourcing creates unemployment in the country while made out of country. Outsourcing also making downsizing in the organizations and terminated because permanent employees require more facilities as compare to outsourced employees. The outsourced company can access the advanced technology through outsourcing and take more benefits with the help of outsourcing.

With the help of education and training a person cannot be more skill for the permanent jobs nor outsourcing in the organizations are made. To overcome outsourcing the government should provide technical institutions for the betterment in the technology sector and also provide the subsides those institutions. Compensation changes should be communicated properly to employees so that they work well and give effective results for organizations. With the help of outsourcing we meet with expert people and gained a lot of knowledge about their work and now the works are in the positions to perform in the better way. 


\section{References:}

1. Admin. (2011, April 11). Outsourcing to Pakistan outsourcing companies continues despite economic slowdown in the West. Retrieved May 22, 2012, from websoftnet: websoftnet.com/outsourcing-pakistan-outsourcing-companies-contin

2. Attaa, B. (2009, September 24). Employment Outsourcing, its Implications on Employer and Employees. Retrieved May 23, 2012, from Propakistani.pk: www.propakistani.pk/

3. Avanade. (2010). Maximize your technology minimize your costs. Avanade Inc. , 5.

4. Barrow, C. (2009). Starting a Business For Dummies. Glasgow: Bell and Bain Wiley publishers UK.

5. By Hans Solli-Saether, P. G. (2011). Managing It Outsourcing Performance. America: Idea Group Inc (IGI USA).

6. BY ADMIN. (2011, April 11). Outsourcing to Pakistan outsourcing companies continues despite economic slowdown in the West. Retrieved may 23, 2012, from websoftnet:

www.websoftnet.com/outsourcing-pakistan-outsourcing-companies-contin.

7. Byham, B. W. (1996). The Outsourcing Questions. INTERNATIONAL,Harvard Business Review, 93-94.

8. keyasu, Y. s. (2004). THE PROGRESS OF OUTSOURCING IN JAP A N. Proceedings of the Fif $t h$ Asia Pacific Industrial Engineering and Management Systems Confer ence $2004,7.8 .16$.

9. Kowalski. (2007, July 25). Pakistan's offshore IT potential held back by political risks. Retrieved May 23, 2012, from Pakistan press foundation: http://www.pakistanpressfoundation.org/

10. Ohnemus, J. (2010). IT Outsourcing and EMployment Growth at the Firm Level. Centre for European Economic Research (ZEW), Research Group Information and Communication Tech-nologies , 1-29.

11. OSCARSSON, B. A. (2002). OUTSOURCING AND INEQUALITY. Journal of International Economics , 1-27.

12. Peter Auer, G. B. (2006). Offshoring and the Internationalization of Employment. Geneva22, Switzerland.: International Institute for Labour Studies.

13. Quoquam Technologies, I. (2012). OUTSOURCING A BUSINESS PERSPECTIVE . www.quoquam.com, 1-7.

14. Siegel, C. M. (2000). The Impacts of Technology, Trade and Outsourcing on Employment and Labour Composition. CENTRE FOR RESEARCH ON GLOBALISATION AND LABOUR MARKETS , 1-22.

15. Suriñach, M. A. (2007). Job Losses, Outsourcing and Relocation: Empirical Evidence Using Microdata. ZBW - Leibniz Information Centre for Economics , 10.

16. Thornton, M. (2004, april 11). How Outsourcing Creates Jobs. Retrieved May 27, 2012, from LewRockwell: www.LewRockwell.com 
17. Wagner, J. L. (1992). Issues In outsourcing . In I. R. Association, Emerging Information Technologies for Competitive Advantage and Economic .. (p. 214). Pennsylvania: Idea Group Inc (IGI).

18. Warner, D. (2011). How to Increase Customer Satisfaction By Outsourcing Your Online Order Fulfillment. Webgistix : Global eCommerce Order Fulfillment Services, 9. 